\title{
BENCHMARKING INTERNATIONAL PROPERTY IN AUSTRALIAN LISTED PROPERTY TRUST PORTFOLIOS
}

\author{
TAN YEN KENG \\ University of Western Sydney
}

\begin{abstract}
The percentage of international property held by listed property trusts (LPTs) has tripled in the last five years. However, the performance of these international properties in LPTs is not directly observable, as no index tracking the performance of this particular LPT sector is currently available. This has complicated LPT sector allocation decision-making as well as benchmarking. Furthermore, the diversification potential of the international LPT sector to the entire property trust portfolio cannot be evaluated. The purpose of this paper is to develop an international LPT-sector performance index, and determine the diversification benefits of adding international LPTs to the property trust portfolio. The findings suggest that the addition of international property to property trust portfolios has resulted in diversification gains.
\end{abstract}

Keywords: Property portfolio, international property diversification, Listed Property Trusts, benchmarking, risk-adjusted returns.

\section{INTRODUCTION}

International property investment has become an increasingly important component within investment portfolios. The major factors contributing to the increased interest in international property investment include geographical, political and economic diversification; lack of local opportunities for property investment; substantial growth in available investment funds; favourable exchange rate and interest rate differentials; and greater array of investment choices (Newell and Worzala, 1995; Worzala and Newell, 1997). Increased recognition of property, an attractive risk-return profile, and growing demand for pension fund asset/liability management have also warranted increased allocations to international property (Steinert and Crowe, 2001).

Australian Listed Property Trusts (LPTs) make up 8\% of the world's listed property (ASX, 2002). With over $55 \%$ of domestic Australian investment grade property held in LPTs, compared to 3\% and 18\% in Europe and North America, the need for Australian LPTs to venture out of the domestic market is imminent (Calder, 2002). Recent acquisitions of international property in the USA, Europe, Asia and New 
Zealand by leading Australian property investors is further evident of this global trend. Among the recent international acquisitions and expansions, AMP Diversified has acquired retail centres in New Zealand; Macquarie Goodman Management and $\mathrm{BT}^{1}$ have major stakes in Singapore REITs (Ascendas); Macquarie CountryWide Trust recently has acquired retail centres in the USA; Westfield Trust has acquired retail centres in New Zealand; Colonial First State Property has property investments in the United Kingdom, Europe and the USA; St George Bank has acquired retail centre interests in New Zealand; Westfield Holdings plans a $\$ 10$ billion expansion in the USA, Europe and Australia; General Property Trust and Centro Properties Group are also looking for investment properties in the USA.

However, the performance of LPTs with international property holdings is not directly observable, as no existing index tracks the performance of this particular LPT sector. Property securities managers intending to implement an international property strategy through LPTs are confronted with the choice of an appropriate benchmark, and consequently, an appropriate weighting of portfolio. Giv`en the recent significant development of international property investment by several major LPTs, it is important that an international LPT performance indicator be developed to enable an effective comparison of this sector with other LPT sectors.

As such, the purpose of this paper is to explore several means of developing an international LPT sector performance index over a 5-year period from June 1997 to June 2002. The performance of the international LPT sector will be compared to the other domestic LPT sectors and the diversification benefits of adding international LPTs to the all-domestic LPT portfolio will also be examined.

\section{LITERATURE REVIEW}

Indices and benchmarking

A benchmark is defined as a standard or point of reference in measuring or judging quality or value (Bailey, Richards and Tierney, 1988). In an investment context, a benchmark represents a passive representation of an investment process. A benchmark should reflect securities selected, weighted in a manner consistent with the investment process (Divecha and Grinold, 1989).

There are four prominent methods for benchmarking performance; namely: index, peer group comparison, normal portfolio and risk-adjusted performance measure (Maxwell and Saint-Pierre, 1998). A new class of index, risk-based index, is introduced to deal with risk levels associated with benchmark portfolios, as most of the indices available are not designed to benchmark risk-return trade-offs (Kaplan and Alldredge, 1997).

${ }^{1}$ BT Funds Management has been replaced by Principal Management in Oct 2003. 
Property indices such as the US NCREIF index have been widely used by property portfolio managers to benchmark their property portfolios. However, McIntosh (1997) cautioned against the use of the NCREIF Property Index as the benchmark for property portfolio managers, as it violates most of the fundamental criteria of a sound benchmark.

As detailed in Bailey (1992a, 1992b), a valid benchmark should embody a number of fundamental properties; specifically:

- Unambiguous: component securities and their weights are clearly delineated

- Investable: benchmark portfolio is replicable and can be held

- Measurable: benchmark's return can be calculated on a frequent basis

- Appropriate: benchmark is consistent with the manager's investment style

- Reflective of current investment opinions: manager has current investment knowledge of the securities that make up the benchmark

- Specified in advance: benchmark is constructed prior to evaluation.

Violation of these properties will affect the robustness of a benchmark in performance evaluation.

In developing the GPR 250 Property Share Index, Eichholtz et al (1998) have pinpointed that an index to be used as a performance benchmark should be replicable. To be replicable, the underlying securities of the index should be liquid and available to investors. Fund managers should be able to track and duplicate such an index, without great difficulties and significant extra trading costs.

\section{Diversification}

The purpose of diversification is to reduce the return volatility of the total portfolio. Theoretically, if economies were not completely integrated, then property returns in different countries would not move together, and risk reduction could be gained through international diversification. As a result, an internationally diversified portfolio would have lower risk than those that are diversified just among domestic property assets.

However, international property investment also raises the concern of uncertainty in currency exchange rate, ongoing management and operation problems, taxation differences and political uncertainty, increased transaction costs, lack of local expertise, and cultural and language differences (Worzala and Newell, 1997).

Several surveys on international property investment have identified the desire for portfolio diversification as the primary motivating factor for international property investment (Newell and Worzala, 1995; Worzala and Newell, 1997). Moreover, economic integration and deregulation, as well as the globalisation of property 
service providers have improved information access to international property investors which have reduced the costs and uncertainty associated with international property investment (McAllister, 1999).

The benefits of international property in enhancing portfolio performance are well documented. Webb, Curcio and Rubens (1988), Chua (1999), Stevenson (1999), Addae-dapaah and Yong (2000), Steinert and Crowe (2001), and Conover, Friday and Sirmans (2002) all found international property had a significant role in the efficient international mixed-asset portfolios. Even though investing in overseas property would assume additional currency risk, additional portfolio diversification was also attained (Newell and Webb, 1996). However, Cheng et al (1999) found that international property is unlikely to produce significant diversification benefits and suggested that investors shouldn't allocate more than $10 \%$ in international property, and $5 \%$ or less for investors with a low risk tolerance.

Due to the fact that direct property cannot be perfectly diversified, indirect property or property securities should be employed by investors to reduce their levels of risk in property investment (De Wit, 1997). Steinert and Crowe (2001) also proposed the use of more liquid and transparent property securities to facilitate global property investment. Stevenson's (2001) study on the role of property securities as diversification tools also found the inclusion of a mix of both domestic and international property securities in a diversified direct property portfolio did lead to significant improvement in portfolio performance.

Differences in property securities' performance over continents (Eichholtz and Koedijk, 1996), low correlation between property shares in emerging and developed markets (Barry, Rodriguez and Lipscomb, 1996), lower internationally correlated property share returns than common stock and bond returns (Eichholtz, 1996), lower correlations among regional property share markets (Eichholtz, 1997b), and weak international dependence of national property markets (Eichholtz et al, 1998) have validated the inclusion of international property securities in property portfolios to achieve a more efficient property portfolio.

Wilson and Okunev $(1996,1999)$ found no long run co-integration relationship between domestic property and equity markets, as well as among international property markets (USA, UK and Australia). In the Asia Pacific region, Garvey, Santry and Stevenson (2001) found no evidence of long-term and short-term linkages between the four largest securitised property markets; namely, Australia, Hong Kong, Japan and Singapore. These results provide evidence that property investors would benefit from diversifying out of an all-domestic portfolio into an internationally diversified portfolio. 
Table 1: Components of LPT-sector indices (June 2002)

\begin{tabular}{|c|c|c|}
\hline Securities Name & ASX Code & $\begin{array}{c}\text { Market Capitalisation } \\
\text { (AUS\$ million) }\end{array}$ \\
\hline UBS-W Leaders 300 & UBSWLDR & 23,666 \\
\hline Westfield Trust & WFT & 6,845 \\
\hline General Property Trust & GPT & 5,342 \\
\hline Westfield America Trust & WFA & 5,264 \\
\hline Stockland Trust Group & SGP & 3,632 \\
\hline Mirvac Group & MGR & 2,583 \\
\hline UBS-W Diversified 300 & DIV300 & 15,649 \\
\hline General Property Trust & GPT & 5,342 \\
\hline Stockland Trust Group & SGP & 3,632 \\
\hline Mirvac Group & MGR & 2,583 \\
\hline Colonial First State Property Trust & CFT & 1.375 \\
\hline AMP Diversified Property Trust & ADP & 1,282 \\
\hline Deutsche Diversified Trust & DDF & 1,056 \\
\hline Tyndall Meridian Trust & TMT & 169 \\
\hline James Fielding Group & JFG & 115 \\
\hline Macquarie Leisure Trust & MLE & 95 \\
\hline UBS-W Retail 300 & RET300 & 17,133 \\
\hline Westfield Trust* & WFT & 6,845 \\
\hline Westfield America Trust* & WFA & 5,264 \\
\hline Gandel Retail Trust & GAN & 1,630 \\
\hline Centro Properties Group & CEP & 1,376 \\
\hline AMP Shopping Centre Trust & ART & 974 \\
\hline Macquarie CountryWide Trust* & MCW & 627 \\
\hline Bunnings Warehouse Property Trust & BWP & 296 \\
\hline Prime Retail Group & PRX & 121 \\
\hline UBS-W Commercial 300 & COM300 & 8,708 \\
\hline Deutsche Office Trust & DOT & 1,492 \\
\hline BT Office Trust & BTO & 1,399 \\
\hline Investa Property Group & IPG & 1,237 \\
\hline AMP Office Trust & $\mathrm{AOF}$ & 1,061 \\
\hline Macquarie Offie Trust & MOF & 1,036 \\
\hline ING Office Trust & IOF & 946 \\
\hline Commonwealth Property Office Fund & CPA & 711 \\
\hline Lend Lease US Office Trust* & LUO & 646 \\
\hline Australian Growth Properties & $\mathrm{AGH}$ & 180 \\
\hline UBS-W Industrial 300 & IND300 & 2,852 \\
\hline Macquarie Goodman Industrial Trust* & MGI & 1,064 \\
\hline ING Industrial Trust & IIF & 924 \\
\hline Deutsche Industrial Trust & DIT & 475 \\
\hline AMP Industrial Trust & AIP & 388 \\
\hline UBS-W Hotel 300 & HOT300 & 298 \\
\hline Grand Hotel Group & GHG & 106 \\
\hline Thakral Holdings Group & THG & 192 \\
\hline ASX300 Property Accumulation Index & & 44,640 \\
\hline
\end{tabular}

* LPT which contains international properties Source: UBS Warburg (2002) 
Gordon, Canter and Webb (1998) and Maurer and Reiner (2002) found significant diversification benefits for including international property securities in the mixedasset portfolio. The diversification benefit was even more significant for low to medium risk portfolios. The source of diversification gains was mainly in riskreduction. Liu and Mei (1998) also found that international property-related securities provided incremental diversification benefits over and above that associated with international stocks. These benefits are relatively more pronounced at lower risk-return levels of the optimal portfolios and are present regardless of whether currency risks are hedged.

\section{DATA AND METHODOLOGY}

Index construction

To better select and apply an index for performance benchmarking purposes, one should understand the index design and computation methodology (Maxwell and Saint-Pierre, 1998). There are three principal index weighting schemes; namely price-weighted, unweighted and market value-weighted.

A price-weighted (or equal-weighted) index is an arithmetic average of current prices. Hence, price movements are influenced by the price changes of the components. The major setback of the price-weighted scheme is the adjustment of the divisor after stock splits will place a downward bias on the index. An index component will lose weight within the index due to simply splitting the stock. An example of a price-weighted index is the Dow Jones Industrial Average.

In an unweighted index, all index components carry equal weight regardless of their price or total market value. The major drawback of an unweighted index is that the level of securities price and market capitalisation do not affect index performance. Indeed, the index return is just the percentage price changes. One example of an unweighted index is the Financial Times Ordinary Share Index.

A market value-weighted (or value-weighted) index is computed by calculating the percentage change in total market value of the component securities in the index. The major problem with a value-weighted index is that firms with greater market capitalisation have a greater impact on the index than do firms with lower market capitalisation. Examples of market value-weighted indices include the S\&P 500, NCREIF, S\&P/ASX indices and UBS-Warburg LPT indices.

Currently, there are several LPT indices maintained/published by the Australian Stock Exchange (ASX) and UBS Warburg. The S\&P/ASX 300 Property Accumulation Index (ASX300PT) contains 30 property trusts listed on the Australian Stock Exchange. UBS Warburg has subdivided these 30 LPTs into 6 major sub-sector indices, which are the UBS-W Leaders 300 (UBSWLDR), UBSW Diversified 300 (DIV300), UBS-W Retail 300 (RET300), UBS-W Commercial 300 (COM300), UBS-W Industrial 300 (IND300), and UBS-W Hotel 300 
(HOT300) (see Table 1 for the components of these indices). Except for the UBSW Leaders 300 (which contains the 5 largest market capitalisation LPTs), each of the 30 LPTs are allotted to one of the 5 sectors according to the characteristic of the trust's underlying property portfolio.

Among the 30 LPTs, five have international property exposure in their trust portfolios. These five LPTs (also referred to as international LPTs) are Westfield Trust (WFT), Westfield America Trust (WFA), Lend Lease US Office Trust (LUO), Macquarie CountryWide Trust (MCW), and Macquarie Goodman Industrial Trust (MGI). Of these five international LPTs, WFA and LUO have 100\% international property portfolios (also referred to as pure international LPTs), while WFT, MCW and MGI have partial international property portfolios (also refer to as partial international LPTs). Table 2 shows the holdings and percentage of international property of these international LPTs at June 2002. Several USA REITs have also included international property in their portfolios (see Table 3), but none of these REITs have $100 \%$ international property portfolios as WFA and LUO in Australia.

Table 2: Profile of international LPTs (June 2002)

\begin{tabular}{lcccccc}
\hline ILPT & Sector & $\begin{array}{c}\text { Total Book } \\
\text { Value* } \\
\text { (\$ million) }\end{array}$ & $\begin{array}{c}\text { Total Book } \\
\text { Value of } \\
\text { international } \\
\text { property } \\
\text { (\$ million) }\end{array}$ & $\begin{array}{c}\text { Percentage of } \\
\text { international } \\
\text { properties } \\
\text { (book value) }\end{array}$ & $\begin{array}{c}\text { No. of } \\
\text { international } \\
\text { properties }\end{array}$ & $\begin{array}{c}\text { Country/location } \\
\text { of international } \\
\text { property }\end{array}$ \\
\hline WFA & Ret. & $8,491.7$ & $8,491.7$ & $100 \%$ & 61 & USA \\
LUO & Com. & 610.9 & 610.9 & $100 \%$ & 8 & USA \\
MCW & Ret. & 795.6 & $103.3+73.6$ & $22.2 \%$ & $16+7$ & New Zealand /USA \\
WFT & Ret. & $8,521.5$ & $1,005.1$ & $11.8 \%$ & 11 & New Zealand \\
MGI & Ind. & $1,587.6$ & 30.3 & $1.9 \%$ & 1 & New Zealand \\
\hline
\end{tabular}

*Total of domestic and international properties in the portfolio

Source: Author's compilation from UBS Warburg and PIR report.

Monthly total return data of all LPTs was provided by UBS Warburg for a 5-year period from June 1997 to June 2002. Details of each LPT portfolio holdings are extracted from PIR's Annual Listed Property Trust Review 1998 - 2003 (PIR, 2003). The market value-weighted index computation scheme is preferred in constructing the new international LPT sector index, mainly due to the consistency with other existing UBS Warburg sector indices, although Oliphant and Corgel (1989) have applied the equal-weighted method when developing open-end and closed-end property fund indices in the USA.

Due to the fact that international properties are held in both pure international LPTs and partial international LPTs portfolios, we have two options to construct the 
international LPT sector index. The first option is to include only pure international LPTs that have $100 \%$ international property in their trust's portfolio. The second option is to use both pure and partial international LPTs. Both approaches have pros and cons.

Table 3: Profile of USA REITs with international property holdings

\begin{tabular}{|c|c|c|}
\hline REIT & Sector & International Property Interest \\
\hline ProLogis (PLD) & Industrial & $\begin{array}{l}\text { Holdings in Japan and throughout Europe } \\
\text { (France, Poland, United Kingdom, } \\
\text { Netherlands, Spain, Germany, Italy, Belgium, } \\
\text { Sweden, Denmark). }\end{array}$ \\
\hline Shurgard Storage (SHU) & Storage & $\begin{array}{l}3 \text { storage facilities in Spain and plan to expand } \\
\text { into Europe. }\end{array}$ \\
\hline Chelsea Property (CPG) & Retail & $\begin{array}{l}2 \text { retail centers in Japan, joint venture in } \\
\text { Mexico and development in South Korea. }\end{array}$ \\
\hline AMP Property (AMB) & Industrial & $\begin{array}{l}2 \text { industrial facilities in Mexico and } 1 \text { in } \\
\text { France. }\end{array}$ \\
\hline Mills Corp (MLS) & Retail & $\begin{array}{l}1 \text { entertaining centre in Spain and is } \\
\text { considering Italy. }\end{array}$ \\
\hline Simon Property (SPG) & Retail & $\begin{array}{l}\text { Joint venture retail projects in Europe ( } 5 \text { in } \\
\text { Poland and } 2 \text { in France). }\end{array}$ \\
\hline Kimco Realty (KIM) & Retail & $\begin{array}{l}1 \text { retail centre in Canada (joint venture) and } 2 \\
\text { retail properties in Mexico. }\end{array}$ \\
\hline Liberty Property (LRY) & Industrial & 11 properties in United Kingdom. \\
\hline
\end{tabular}

Source: Courtesy of Michael Young from RREEF.

Option one is straightforward and not affected by the concern of how to determine the performance of individual international property in the partial international LPT portfolio. However, this method excludes international properties held in partial international LPTs, which accounts for $22.2 \%$ of total international property in overall LPT portfolios (see Table 4).

Option two combines both pure and partial international LPTs in order to capture all international property components in the international LPT sector index. However, as mentioned before, the performance detail of individual international 
properties is not available, simply because of confidentiality and is not released by individual LPTs. Therefore, international property performance cannot be stripped out directly on an individual property basis. Thus, we have to make an assumption that the contribution of the international property is proportionate to its weight in the relevant LPT's property portfolio.

Table 4: Average weighting of international LPTs in international LPT index

\begin{tabular}{ccc}
\hline International LPT & Option 1 & Option 2 \\
\hline WFA & $92.2 \%$ & $72.2 \%$ \\
LUO & $7.8 \%$ & $5.6 \%$ \\
WFT & $0.0 \%$ & $21.1 \%$ \\
MCW & $0.0 \%$ & $1.0 \%$ \\
MGI & $0.0 \%$ & $0.1 \%$ \\
\hline
\end{tabular}

To better evaluate the performance of international property, both options are applied to construct two sets of indices. $\mathrm{INT}_{1}$ will represent an international property sector index based on Option 1, while $\mathrm{INT}_{2}$ refers to an international property sector index based on Option 2.

Construction of $\mathrm{INT}_{1}$ is straightforward. Pure international LPTs, WFA and LUO, will be removed from their existing sectors and regrouped under a new heading, $\mathrm{INT}_{1}$. A market value-weighted scheme will be used to derive $\mathrm{INT}_{1}$.

Table 5: Inclusion dates of international LPTs into international-LPT index

\begin{tabular}{cc}
\hline INTERNATIONAL LPT & Date \\
\hline WFA & June $1997^{*}$ \\
WFT & December 1998 \\
MCW & October 2000 \\
LUO & April $2000^{* *}$ \\
MGI & July 2001 \\
\hline
\end{tabular}

*WFA was listed in June 1996. ** LUO was listed in Dec 1999, but the first available data by UBS Warburg started on Apr 2000. Source: Author's compilation from PIR report.

Due to the fact that the performance of international properties in partial international LPTs is not directly observable, the construction of $\mathrm{INT}_{2}$ is exploratory in nature. $\mathrm{INT}_{2}$ is designed to be flexible enough to accommodate the 
changing international property weightings. Furthermore, the inclusion dates ${ }^{2}$ of these five international LPTs into the index are different (see Table 5), with most of the international property revalued at different times. Hence, $\mathrm{INT}_{2}$ should also take into account these timing and revaluation variations.

$\mathrm{INT}_{2}$ has the following equation:

$$
\left(\left(\frac{\Sigma \mathbf{M}_{\text {in }} \mathbf{R}_{\text {in }} \mathbf{W}_{\text {in }}}{\Sigma \mathbf{M}_{\text {in }} \mathbf{W}_{\text {in }}}\right)+1\right) \times \text { base value }_{n-1}
$$

where $M_{\text {in }}$ represents the market capitalisation for international LPT $i, R_{\text {in }}$ is the total return for ith international LPT, and $W_{\text {in }}$ is the percentage of total international property in ith international LPT's portfolio. $n$ is the corresponding month and the first base value is set at $100 . W_{\text {in }}$ is derived as follows:

$$
\mathbf{W}_{\text {in }}=\frac{B \mathbf{I}_{\text {in }}}{\mathbf{B T _ { \text { in } }}}
$$

where $B I_{i n}$ is the book value of total international property in ith international LPT in month $n, B T_{i n}$ is the total book value of all property in international LPT $i$. The computation of $W_{\text {in }}$ takes into account the revaluation of property in the portfolio, as the monthly updated book value for each property is used.

In constructing $\mathrm{INT}_{2}$, we assume that the contribution of the international property is proportionate to its weight in the portfolio and $W_{i n} R_{i n}$ is an unbiased representation of the underlying international property performance. We have to make this assumption because details of performance of individual properties are not available; therefore, the effect is not able to be stripped out directly on an individual property basis. Hence, $W_{i n} R_{i n}$ represents the portion of performance that is attributable to international property while $\left(1-W_{i n}\right) R_{\text {in }}$ represents domestic property performance in the $i t h$ international LPT's portfolio.

As shown in Table 2, international LPTs were currently included in three different UBS Warburg sector indices. To strip out the international LPT components, two new series of indices are needed. For this purpose, 14 indices (7 for each option) are constructed, as opposed to the 5 original UBS Warburg sector indices. Table 6 presents the components of these 14 indices. The new indices include internationalLPT index $\left(\mathrm{INT}_{1}\right.$ and $\left.\mathrm{INT}_{2}\right)$, domestic-retail LPT index $\left(\mathrm{DRET}_{1}\right.$ and $\left.\mathrm{DRET}_{2}\right)$, domestic-commercial LPT index $\left(\mathrm{DCOM}_{1}\right.$ and $\left.\mathrm{DCOM}_{2}\right)$, domestic-industrial LPT index $\left(\mathrm{DIND}_{1}\right.$ and $\left.\mathrm{DIND}_{2}\right)$, domestic-diversified LPT index ${ }^{3}\left(\mathrm{DDIV}_{1}\right.$ and $\left.\mathrm{DDIV}_{2}\right)$

\footnotetext{
${ }^{2}$ The date which one international LPT was first listed or the date which first international property is included into the trust's portfolio.

${ }^{3}$ Both DDIV $_{1}$ and DDIV $_{2}$ are equivalent to UBSW DIV300 because no international property is in any of the trusts in this sector.
} 
Table 6: New components of LPT-sector indices

\begin{tabular}{|c|c|c|c|}
\hline \multicolumn{2}{|l|}{ Option 1} & \multicolumn{2}{|l|}{ Option 2} \\
\hline International LPT Index 1 & INT $_{1}$ & International LPT Index 2 & INT $_{2}$ \\
\hline Westfield America Trust & WFA & Westfield America Trust & WFA \\
\hline Lend Lease US Office Trust & LUO & Lend Lease US Office Trust & LUO \\
\hline & & Westfield Trust* & WFT \\
\hline & & Macquarie Goodman Industrial Trust* & MGI \\
\hline & & Macquarie CountryWide Trust* & $\mathrm{MCW}$ \\
\hline Domestic-diversified LPT Index & DDIV $_{1}$ & Domestic-diversified LPT Index & $\mathrm{DDIV}_{2}$ \\
\hline General Property Trust & GPT & General Property Trust & GPT \\
\hline Stockland Trust Group & SGP & Stockland Trust Group & SGP \\
\hline Mirvac Group & MGR & Mirvac Group & MGR \\
\hline Colonial First State Property Trust & CFT & Colonial First State Property Trust & CFT \\
\hline AMP Diversified Property Trust & ADP & AMP Diversified Property Trust & ADP \\
\hline Deutsche Diversified Trust & DDF & Deutsche Diversified Trust & DDF \\
\hline Tyndall Meridian Trust & TMT & Tyndall Meridian Trust & TMT \\
\hline James Fielding Group & JFG & James Fielding Group & JFG \\
\hline Macquarie Leisure Trust & MLE & Macquarie Leisure Trust & MLE \\
\hline Domestic-retail LPT Index & DRET $_{1}$ & Domestic-retail LPT Index & DRET $_{2}$ \\
\hline Westfield Trust & WFT & Westfield Trust* & WFT \\
\hline Gandel Retail Trust & GAN & Gandel Retail Trust & GAN \\
\hline Centro Properties Group & CEP & Centro Properties Group & CEP \\
\hline AMP Shopping Centre Trust & ART & AMP Shopping Centre Trust & ART \\
\hline Macquarie CountryWide Trust* & MCW & Macquarie CountryWide Trust* & $\mathrm{MCW}$ \\
\hline Bunnings Warehouse Property Trust & BWP & Bunnings Warehouse Property Trust & BWP \\
\hline Prime Retail Group & PRX & Prime Retail Group & PRX \\
\hline Domestic-commercial LPT Index & $\mathrm{DCOM}_{1}$ & Domestic-commercial LPT Index & $\mathrm{DCOM}_{2}$ \\
\hline Deutsche Office Trust & DOT & Deutsche Office Trust & DOT \\
\hline BT Office Trust & BTO & BT Office Trust & BTO \\
\hline Investa Property Group & IPG & Investa Property Group & IPG \\
\hline AMP Office Trust & AOF & AMP Office Trust & $\mathrm{AOF}$ \\
\hline Macquarie Offie Trust & MOF & Macquarie Offie Trust & MOF \\
\hline ING Office Trust & IOF & ING Office Trust & IOF \\
\hline Commonwealth Property Office Fund & $\mathrm{CPA}$ & Commonwealth Property Office Fund & CPA \\
\hline Australian Growth Properties & $\mathrm{AGH}$ & Australian Growth Properties & $\mathrm{AGH}$ \\
\hline Domestic-industrial LPT Index & DIND $_{1}$ & Domestic-industrial LPT Index & DIND $_{2}$ \\
\hline Macquarie Goodman Industrial Trust & MGI & Macquarie Goodman Industrial Trust* & MGI \\
\hline ING Industrial Trust & IIF & ING Industrial Trust & IIF \\
\hline Deutsche Industrial Trust & DIT & Deutsche Industrial Trust & DIT \\
\hline AMP Industrial Trust & AIP & AMP Industrial Trust & AIP \\
\hline Domestic-hotel LPT Index & DHOT $_{1}$ & Domestic-hotel LPT Index & DHOT $_{2}$ \\
\hline Grand Hotel Group & GHG & Grand Hotel Group & GHG \\
\hline Thakral Holdings Group & THG & Thakral Holdings Group & THG \\
\hline Overall LPT Index (ex WFA \& LUO) & DLPT $_{1}$ & $\begin{array}{l}\text { Overall LPT Index (ex WFA, LUO, } \\
\text { international portion of WFT, MCW \& } \\
\text { MGI) }\end{array}$ & DLPT $_{2}$ \\
\hline
\end{tabular}

* These partial international LPTs were accounted for in both international-LPT indices and one other domestic-sector index. 
and domestic-hotel LPT index ${ }^{4}\left(\mathrm{DHOT}_{1}\right.$ and $\left.\mathrm{DHOT}_{2}\right)$. An overall LPT index $\left(\mathrm{DLPT}_{1}\right.$ and $\left.\mathrm{DLPT}_{2}\right)$, which encompasses all LPTs excluding international LPTs, is also constructed for the purpose of contrasting the performance of international and domestic LPT portfolios. The performance of the various LPT sectors is then evaluated.

WFA is removed from the domestic-retail LPT index and relocated to the international-LPT index. LUO is removed from the domestic-commercial LPT index and moved to the international-LPT index. The difference between $\mathrm{DRET}_{1}$ and $\mathrm{DRET}_{2}$ is that $\mathrm{DRET}_{1}$ uses the total market value of WFT and MCW in deriving the index, while $\mathrm{DRET}_{2}$ uses the apportioned market capitalisation and rate of return from the two partial international LPTs. The same methodology is applied to $\mathrm{DIND}_{2}$ and $\mathrm{DLPT}_{2}$.

Figure 1: Percentage of international LPTs in LPT portfolio

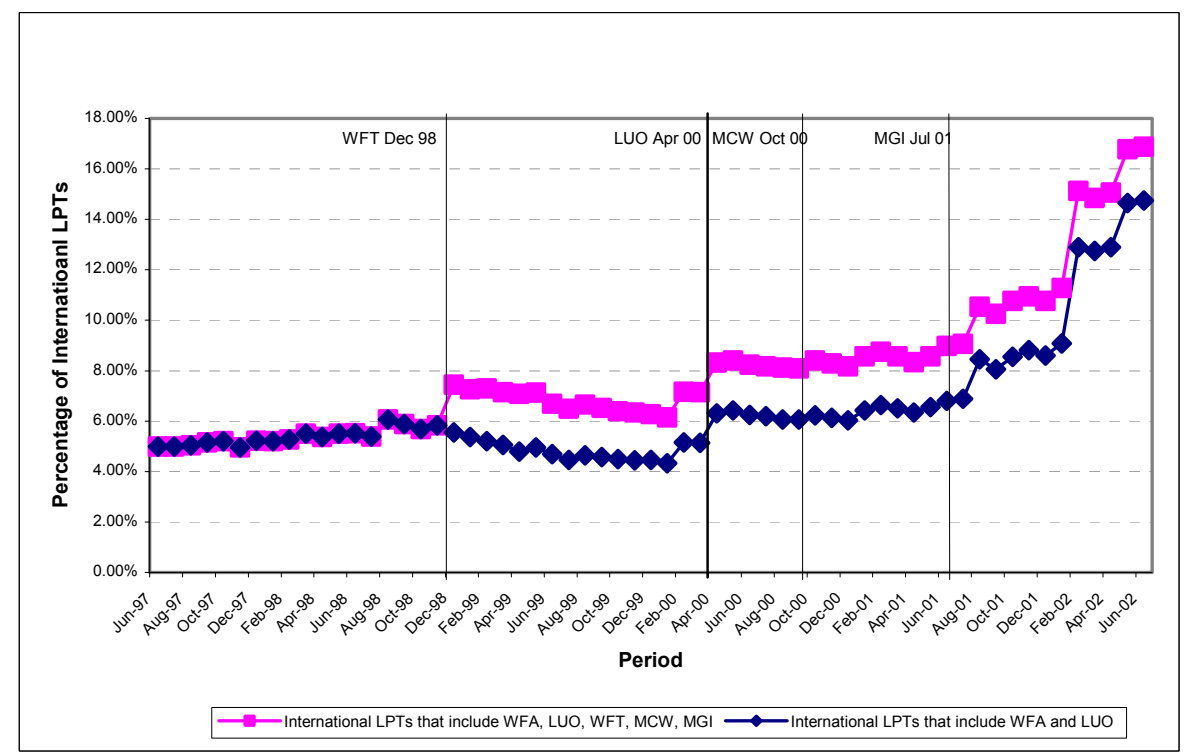

\section{Diversification}

Efficient property trust portfolios are constructed to evaluate the diversification benefits of adding international LPTs to domestic LPT portfolios. Two efficient frontiers will be constructed. A domestic property LPTs efficient frontier will be constructed by optimising (applying the Solver function in Excel) the portfolio allocations of the five domestic LPT sector indices, namely DRET, DCOM, DIND,

${ }^{4}$ Both $\mathrm{DHOT}_{1}$ and $\mathrm{DHOT}_{2}$ are equivalent to UBSW HOT300 because no international property is in any of the trusts in this sector. 
DDIV and DHOT. International LPTs (INT) will be added to the portfolio to generate another efficient frontier. Diversification benefits of adding international property can be established if the efficient frontier with INT dominates the efficient frontier without INT.

\section{RESULTS AND DISCUSSION}

Figure 1 depicts the percentage of international property in the Australian LPT sector. For the period between June 1997 and November 1998, only one international LPT (WFA) was added into the international LPT index. WFT was added to the international-LPT index in December 1998; LUO in February 2000; MCW in October 2000; and MGI in July 2001 (see Table 5). With the addition of more international LPTs/international properties, the percentage of international property in the total LPT portfolio has increased from less than $6 \%$ before December 1998 to $14.7 \%$ (for pure international LPTs) and 17\% (for combined pure and partial international LPTs) in June 2002.

The performance of various sector-specific LPT indices over the 5-year period from June 1997 to June 2002 is presented in Table 7. INT 1 outperformed all other sector indices in terms of both absolute and risk-adjusted returns. On average, $\mathrm{INT}_{1}$ outperformed $\mathrm{DLPT}_{1}$ by more than $9.5 \%$ annualised average return. The riskadjusted return of $\operatorname{INT}_{1}(1.50)$ is 0.45 higher than $\mathrm{DLPT}_{1}$ and 0.25 higher than the best performing domestic LPT sub-sector index $\left(\mathrm{DIND}_{1}\right)$. The out-performance of $\mathrm{INT}_{1}$ index against $\mathrm{DLPT}_{1}$ index and overall LPT portfolio index (ASX300PT) is clearly depicted in Figure 2.

Table 7: Performance of LPT-sector indices (June 1997 - June 2002)

\begin{tabular}{lrrc}
\hline Indices & Return & \multicolumn{1}{c}{ Risk } & Risk-adjusted Return* \\
\hline INT $_{1}$ & $21.21 \%$ & $14.17 \%$ & 1.50 \\
DLPT $_{1}$ & $11.50 \%$ & $10.93 \%$ & 1.05 \\
DRET $_{1}$ & $14.79 \%$ & $12.68 \%$ & 1.17 \\
DCOM $_{1}$ & $9.47 \%$ & $10.67 \%$ & 0.89 \\
DIND $_{1}$ & $12.42 \%$ & $9.90 \%$ & 1.25 \\
DDIV $_{1}$ & $11.73 \%$ & $11.85 \%$ & 0.99 \\
DHOT $_{1}$ & $-2.76 \%$ & $17.21 \%$ & -0.16 \\
ASX300 PT & $12.14 \%$ & $10.82 \%$ & 1.12 \\
\hline
\end{tabular}

* Rate of return divided by risk.

Table 8 presents the correlation matrix between the returns on the sector-specific LPT indices. The correlation between $\mathrm{INT}_{1}$ and $\mathrm{DLPT}_{1}$ index is 0.64 . The correlation between $\mathrm{INT}_{1}$ and most other domestic LPT sub-sector indices is below 0.66 , with an average correlation of 0.51 . The moderate correlation implies the 
existence of possible diversification benefits of adding international LPTs to the property trusts' portfolio.

Figure 2: Comparison of international LPTs Index, LPT Index (ex international LPTs) and all LPT Index: June 1997 to June 2002

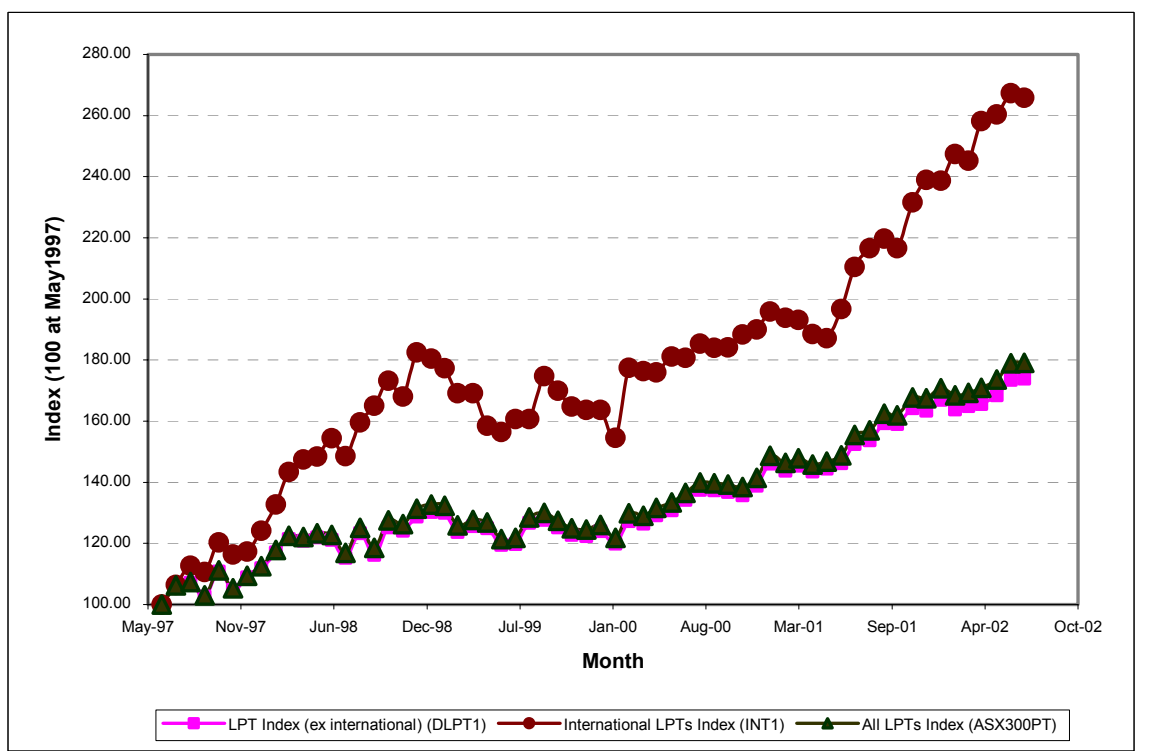

Table 8: Correlation matrix (June 1997 - June 2002)

\begin{tabular}{l|cccccccc}
\hline & $\mathrm{INT}_{1}$ & DLPT $_{1}$ & DRET $_{1}$ & DCOM $_{1}$ & DIND $_{1}$ & DDIV $_{1}$ & DHOT $_{1}$ & ASX300PT \\
\hline INT $_{1}$ & $\mathbf{1 . 0 0 0}$ & & & & & & & \\
DLPT $_{1}$ & $\mathbf{0 . 6 4 2}$ & 1.000 & & & & & & \\
DRET $_{1}$ & $\mathbf{0 . 6 6 4}$ & 0.952 & 1.000 & & & & & \\
DCOM $_{1}$ & $\mathbf{0 . 5 3 5}$ & 0.894 & 0.778 & 1.000 & & & & \\
DIND $_{1}$ & $\mathbf{0 . 4 7 1}$ & 0.810 & 0.688 & 0.788 & 1.000 & & & \\
DDIV $_{1}$ & $\mathbf{0 . 6 3 0}$ & 0.983 & 0.922 & 0.842 & 0.763 & 1.000 & & \\
DHOT $_{1}$ & $\mathbf{0 . 2 4 2}$ & 0.323 & 0.195 & 0.264 & 0.435 & 0.317 & 1.000 & \\
ASX300PT & $\mathbf{0 . 6 8 7}$ & 0.998 & 0.953 & 0.889 & 0.807 & 0.981 & 0.330 & 1.000 \\
\hline
\end{tabular}

The performance of $\mathrm{INT}_{2}$ is presented in Table 9. Similar to $\mathrm{INT}_{1}, \mathrm{INT}_{2}$ outperformed all other sector indices in terms of both absolute and risk-adjusted returns. On average, $\mathrm{INT}_{2}$ outperformed $\mathrm{DLPT}_{2}$ by $8.9 \%$, with marginally higher risk. The risk-adjusted return of $\mathrm{INT}_{2}(1.54)$ is 0.50 higher than $\mathrm{DLPT}_{2}$ and 0.04 higher than $\mathrm{INT}_{1}$. The performance of both international LPT indices is presented 
in Figure 3. The difference in performance for $\mathrm{INT}_{1}$ and $\mathrm{INT}_{2}$ is almost unnoticeable until mid 2001, where the gap between $\mathrm{INT}_{1}$ and $\mathrm{INT}_{2}$ started to widen.

Figure 3: Comparison of two international LPT Indices (INT 1 and INT $)$, and ASX300PT Index: June 1997 - June 2002

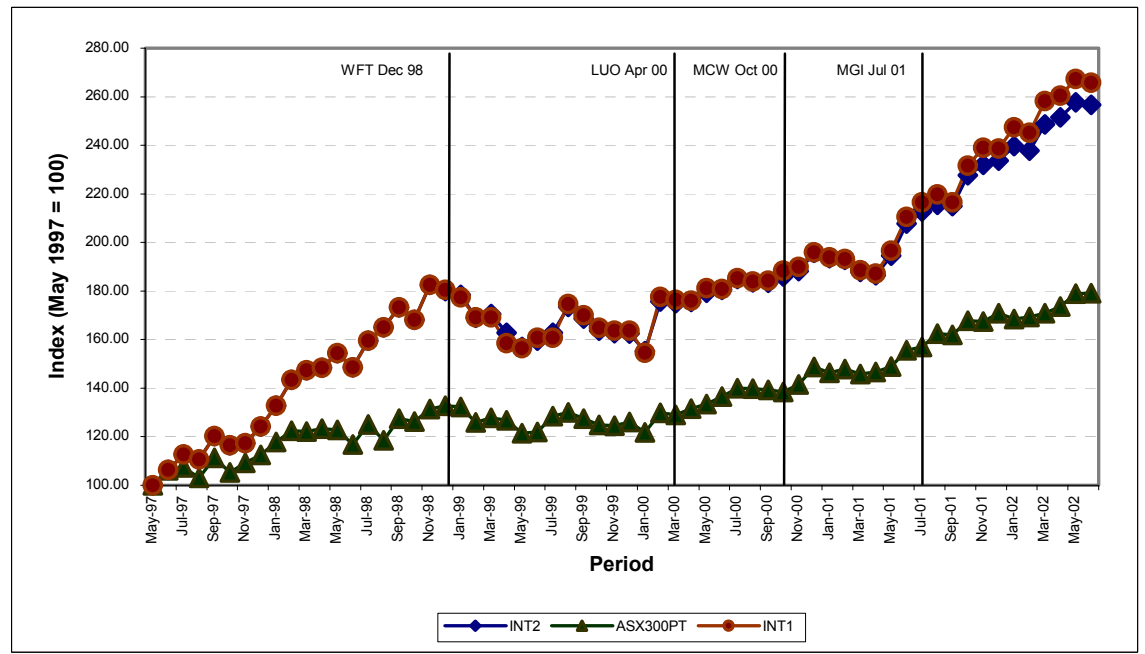

The difference in performance between the indices calculated using two different methodologies is not very significant. This resemblance may have resulted from the domination of WFA in both international-LPT indices series. WFA accounts for $92 \%$ of the average weightings in $\mathrm{INT}_{1}$ and about $72 \%$ in $\mathrm{INT}_{2}$ (see Table 2). However, as more international LPTs are incorporated ${ }^{5}$ in the future, the domination of WFA should diminish. The most obvious variations are between the risk and return of $\mathrm{INT}_{1}$ and $\mathrm{INT}_{2}$, with about $1 \%$ difference in both rates, which translates into 0.04 differences in risk-adjusted return.

Table 10 presents the correlation matrix between $\mathrm{INT}_{2}$ and the other sector-specific LPT indices. The correlation between $\mathrm{INT}_{2}$ and $\mathrm{DLPT}_{2}$ index is 0.72 . The correlation between the international-LPT index and most other domestic LPT subsector indices is below 0.70 , with an average correlation of 0.55 . The moderate correlation implies the existence of possible diversification gains.

\footnotetext{
${ }^{5}$ Macquarie ProLogis Trust has 67 properties in the USA and Mexico was listed on the ASX on 26 June 2002; AMP Diversified Property Trust has acquired 3 New Zealand retail properties in August-September 2002; Principal Financial Group (formally know as BT Funds Management) plans to list a substantial portfolio of US office buildings (and also targeting Asia property) on the ASX; Macquarie plans to list a portfolio of US apartment properties.
} 
Table 9: Performance of LPT-sector indices (June 1997 - June 2002)

\begin{tabular}{lccc}
\hline Indices & Return & Risk & Risk-adjusted Return* \\
\hline $\mathrm{INT}_{2}$ & $20.37 \%$ & $13.20 \%$ & 1.54 \\
$\mathrm{DLPT}_{2}$ & $11.52 \%$ & $11.09 \%$ & 1.04 \\
$\mathrm{DRET}_{2}$ & $14.49 \%$ & $12.27 \%$ & 1.18 \\
$\mathrm{DCOM}_{2}$ & $9.47 \%$ & $10.67 \%$ & 0.89 \\
$\mathrm{DIND}_{2}$ & $12.05 \%$ & $9.98 \%$ & 1.21 \\
$\mathrm{DDIV}_{2}$ & $11.73 \%$ & $11.85 \%$ & 0.99 \\
$\mathrm{DHOT}_{2}$ & $-2.76 \%$ & $17.21 \%$ & -0.16 \\
$\mathrm{ASX}_{300} \mathrm{PT}$ & $12.14 \%$ & $10.82 \%$ & 1.12 \\
\hline * Rate of return divided by risk & &
\end{tabular}

In order to estimate the diversification benefits of international LPTs (proxied by $\mathrm{INT}_{1}$ ), an efficient portfolio is constructed using ex-post data. Figure 4 illustrates two efficient portfolios: a domestic property trust portfolio consisting of domesticretail LPT index $\left(\mathrm{DRET}_{1}\right)$, domestic-commercial LPT index $\left(\mathrm{DCOM}_{1}\right)$, domesticdiversified LPT index $\left(\mathrm{DDIV}_{1}\right)$, domestic-industrial LPT index $\left(\mathrm{DIND}_{1}\right)$, domestichotel LPT index $\left(\mathrm{DHOT}_{1}\right)$, and a total property trust portfolio consisting of this domestic property trust portfolio plus international LPTs.

Table 10: Correlation matrix (June 1997 - June 2002)

\begin{tabular}{l|cccccccc}
\hline & $\mathrm{INT}_{2}$ & $\mathrm{DLPT}_{2}$ & $\mathrm{DRET}_{2}$ & $\mathrm{DCOM}_{2}$ & $\mathrm{DIND}_{2}$ & $\mathrm{DDIV}_{2}$ & $\mathrm{DHOT}_{2}$ & $\mathrm{ASX300PT}$ \\
\hline $\mathrm{INT}_{2}$ & $\mathbf{1 . 0 0 0}$ & & & & & & & \\
$\mathrm{DLPT}_{2}$ & $\mathbf{0 . 7 2 4}$ & 1.000 & & & & & & \\
$\mathrm{DRET}_{2}$ & $\mathbf{0 . 7 5 0}$ & 0.950 & 1.000 & & & & & \\
$\mathrm{DCOM}_{2}$ & $\mathbf{0 . 5 8 1}$ & 0.882 & 0.776 & 1.000 & & & & \\
$\mathrm{DIND}_{2}$ & $\mathbf{0 . 5 1 7}$ & 0.800 & 0.687 & 0.793 & 1.000 & & & \\
$\mathrm{DDIV}_{2}$ & $\mathbf{0 . 6 9 9}$ & 0.985 & 0.922 & 0.842 & 0.762 & 1.000 & & \\
DHOT $_{2}$ & $\mathbf{0 . 2 2 5}$ & 0.321 & 0.205 & 0.264 & 0.448 & 0.317 & 1.000 & \\
ASX300PT & $\mathbf{0 . 7 5 6}$ & 0.996 & 0.952 & 0.889 & 0.806 & 0.981 & 0.330 & 1.000 \\
\hline
\end{tabular}

As depicted in Figure 4, a total property trust portfolio consisting of international and domestic LPTs is more efficient and dominates the domestic LPT's portfolio. At the lower level of the risk/return spectrum (12.5\% annual return), overall portfolio risk is reduced by $0.7 \%$ through the addition of international LPTs $\left(\mathrm{INT}_{1}\right)$. Overall portfolio risk is reduced even more for higher levels of portfolio returns. At a $14 \%$ annual return level, overall portfolio risk is reduced by $3.4 \%$ through the addition of $\mathrm{INT}_{1}$. On the other hand, at a same risk level $(10 \%)$, the mixed international and domestic LPTs portfolio enhances the portfolio's annual return by $4.5 \%$. As demonstrated, at all levels of the risk/return spectrum, the addition of international LPTs significantly adds diversification benefits to the property trusts' portfolio. 
Figure 4: Efficient Frontier: optimal LPTs portfolio with \& without international LPTs

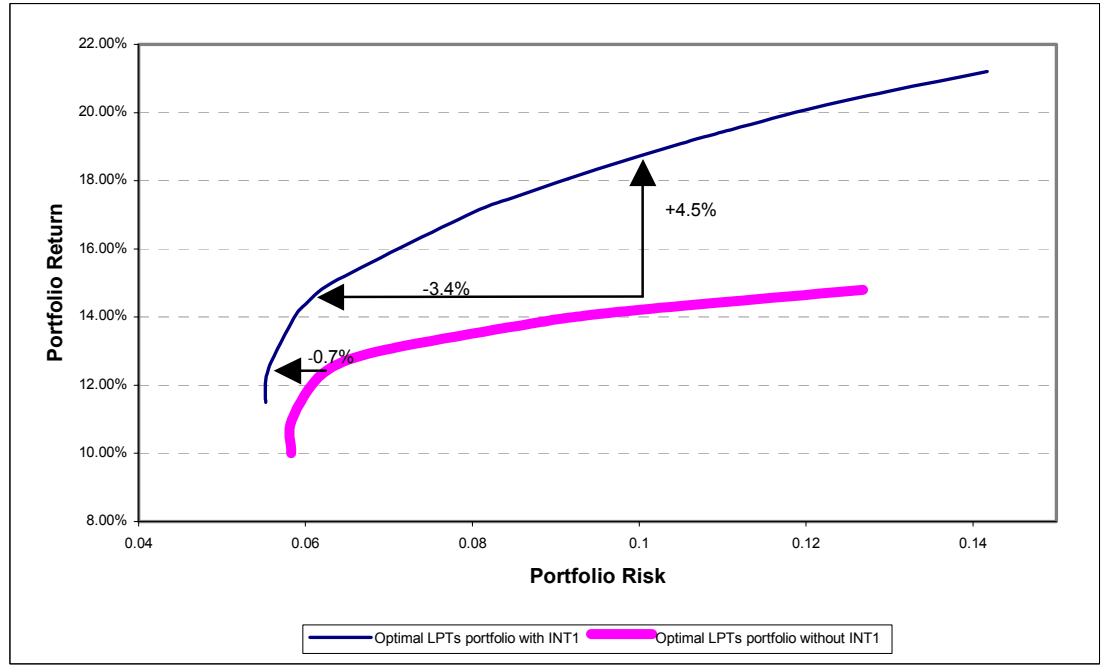

Figure 5 depicts the allocation of LPT sectors in the efficient portfolio across various risk levels. International LPTs have a significant allocation at all risk levels, with the allocation increasing as the portfolio risk increases.

Figure 5: Efficient LPTs Portfolio: June 1997 - June 2002

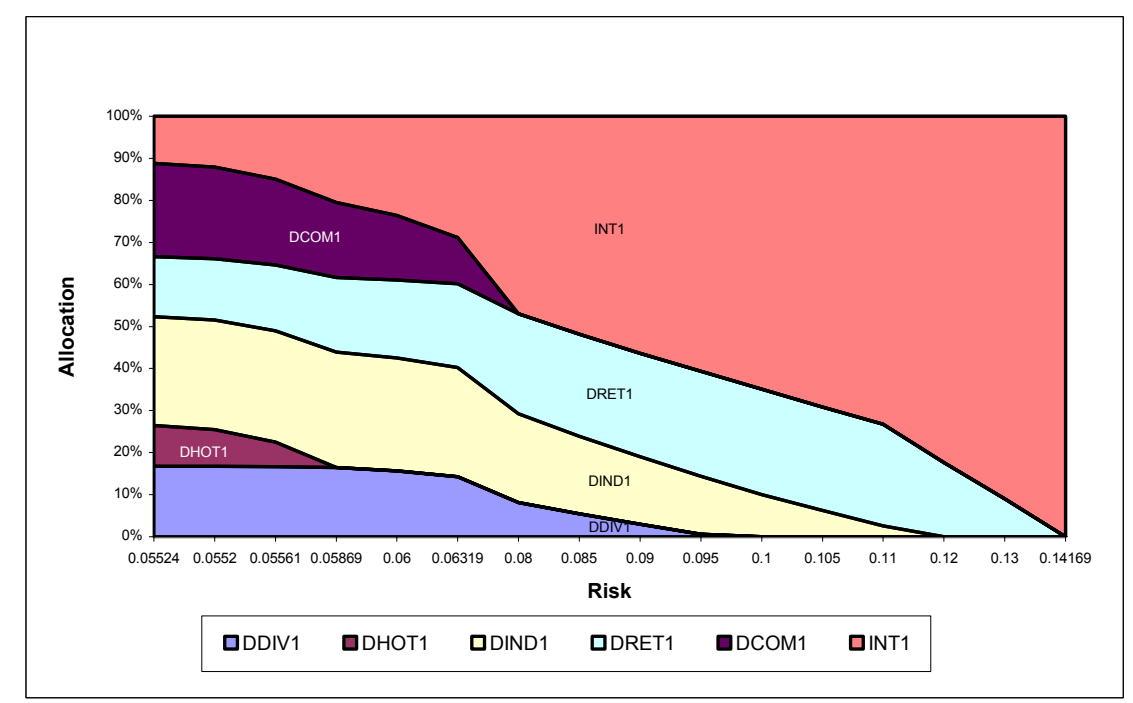

Pacific Rim Property Research Journal, Vol 10, No 1 
Figure 6: Comparison of Efficient Frontiers (with and without) INT $_{1}$ vs INT $_{2}$ : June 1997 - June 2002

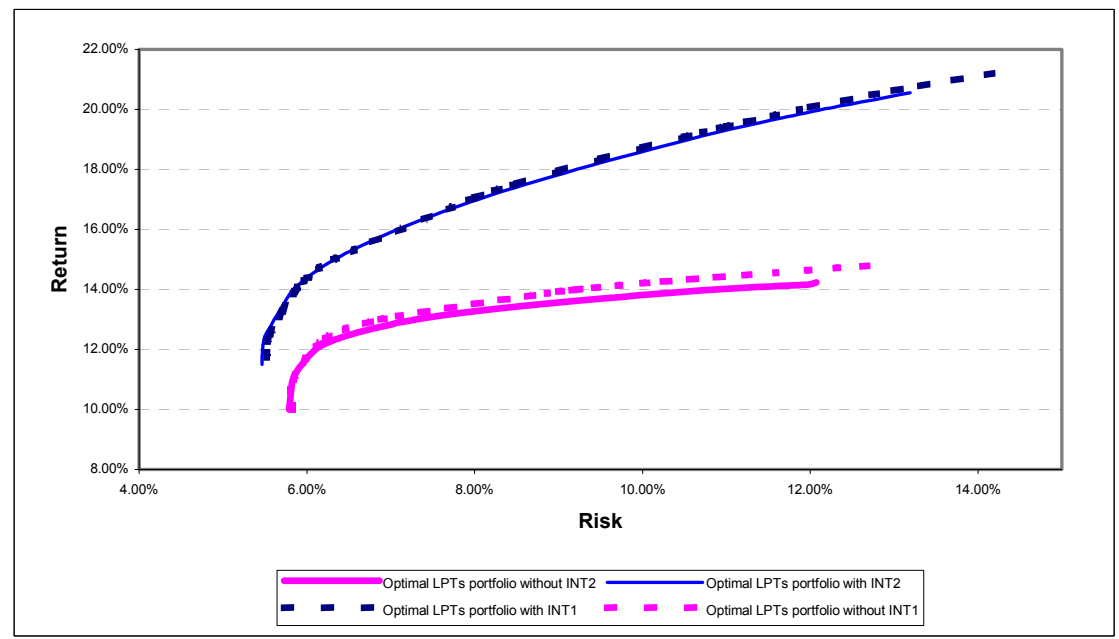

Figure 6 presents the comparison of efficient frontiers constructed from the two separate series of indices. As suggested by the minor differences in performance and correlation numbers between $\mathrm{INT}_{1}$ and $\mathrm{INT}_{2}$, the variation in efficient frontiers was small. However, the optimal LPT portfolio without $\mathrm{INT}_{2}$ is consistently dominated by the optimal LPT portfolio without $\mathrm{INT}_{1}$. This finding demonstrates that the optimal domestic LPT portfolio (based on Option 2 methodology) is less efficient, which can be attributed to the inclusion of partial international LPTs. Apportioning partial international LPTs in both domestic and international portfolio has increased the correlations between associated LPT sectors (as evident in Table 7 and 9), thus reducing the diversification gains. Nonetheless, both sets of efficient frontiers exhibit significant diversification benefits by adding international LPTs to the domestic LPTs portfolio. Figure 7 is also consistent with Figure 5 where international LPTs have a significant allocation at all risk levels, with the allocation increasing as the portfolio risk increases.

When one examines the out-performance of the international-LPT index illustrated in Figures 2 and 3, the superior performance of the international-LPT index was basically due to the out-performance of the international-LPT index during the initial period of the study. For the period between June 1997 and November 1998, the performance of the international-LPT index, in essence, duplicated the performance of a single international LPT, which is WFA. The second international LPT was added to the international-LPT index in Dec 1998 (for $\mathrm{INT}_{2}$ ) and April 2000 (for $\mathrm{INT}_{1}$ ). Therefore, to separate the effect of superior 
performance due to a single international LPT in the initial period, the indices are recalibrated to a new base period at Dec 1998.

Figure 7: Efficient LPTs Portfolio: June 1997 - June 2002

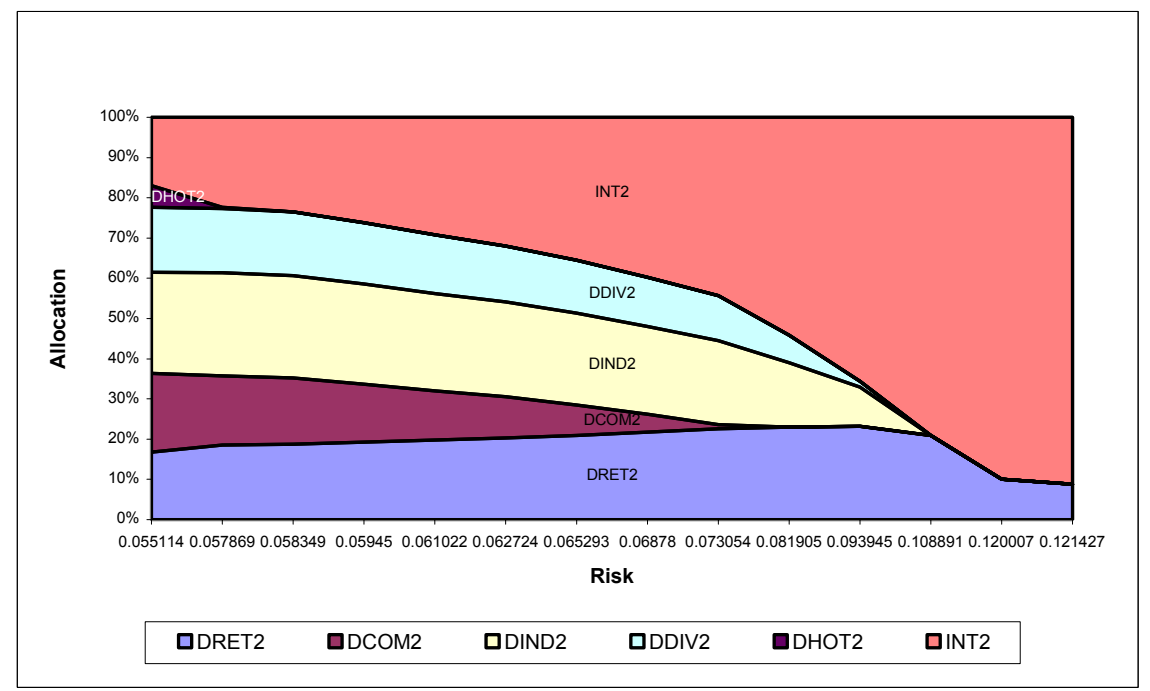

The recalibration of the indices to Dec 1998 has affected the subsequent performance results. The performance of all indices from Dec 1998 to June 2002 is presented in Table 11. The international-LPT index was no longer the best performing sector. However, $\mathrm{INT}_{2}$ still outperforms $\mathrm{DLPT}_{2}$ by about $1.7 \%$ in return, but with significantly higher risk.

Figure 8 illustrates the performance of $\mathrm{INT}_{2}$ over Dec 1998 - June 2002. The performance of $\mathrm{INT}_{2}$ is compared against the domestic-LPT index (DLPT $)$ and the ASX300PT index. INT 2 under performed $\mathrm{DLPT}_{2}$ in 1999-2001, but later in 2001, $\mathrm{INT}_{2}$ surpassed $\mathrm{DLPT}_{2}$, and since then has outperformed DLPT $\mathrm{D}_{2}$.

Table 11: Performance of LPT-sector indices (Dec 1998 - June 2002)

\begin{tabular}{lccc}
\hline Indices & Return & Risk & Risk-adjusted Return* \\
\hline $\mathrm{INT}_{2}$ & $9.98 \%$ & $11.70 \%$ & 0.85 \\
$\mathrm{DLPT}_{2}$ & $8.28 \%$ & $8.56 \%$ & 0.97 \\
$\mathrm{DRET}_{2}$ & $6.86 \%$ & $8.46 \%$ & 0.81 \\
$\mathrm{DCOM}_{2}$ & $11.12 \%$ & $9.02 \%$ & 1.23 \\
$\mathrm{DIND}_{2}$ & $13.12 \%$ & $8.19 \%$ & 1.60 \\
$\mathrm{DDIV}_{2}$ & $8.37 \%$ & $8.85 \%$ & 0.95 \\
$\mathrm{DHOT}_{2}$ & $2.57 \%$ & $17.00 \%$ & 0.15 \\
$\mathrm{ASX300} \mathrm{PT}^{*}$ & $9.03 \%$ & $8.25 \%$ & 1.09 \\
\hline
\end{tabular}


Figure 8: Comparison of international LPT Index, domestic LPT Index and all LPT Index (ASX300PT): December 1998 - June 2002

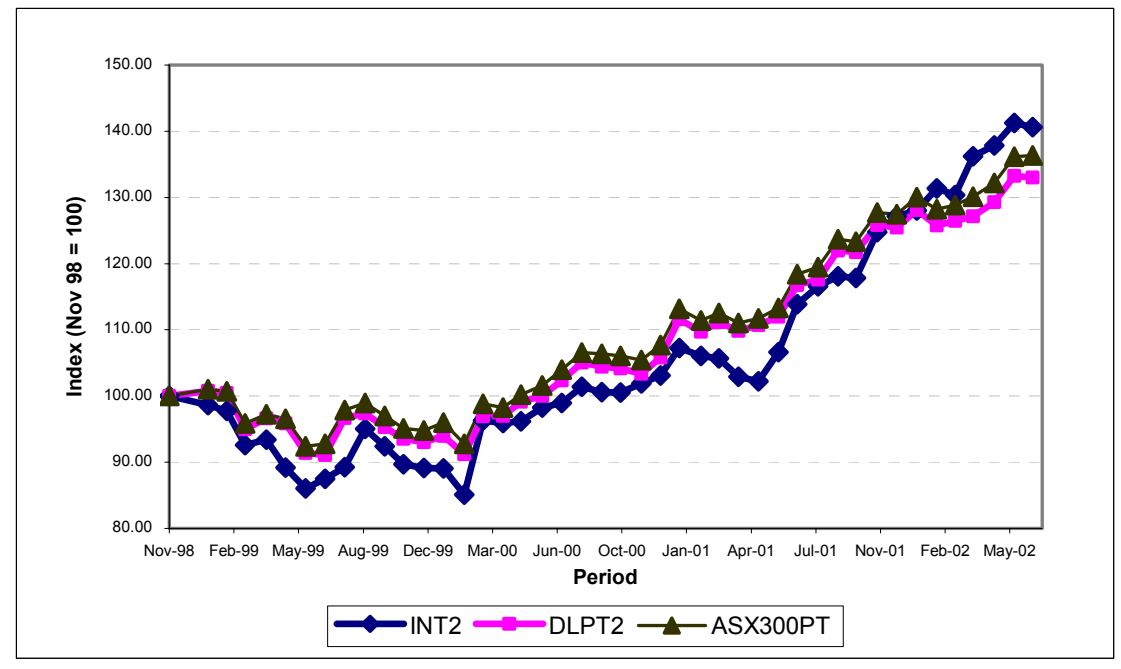

Table 12 presents the correlation matrix between the returns on sector-specific LPT indices over Dec 1998 to June 2002. The correlation does not vary significantly against the previous 1997-2002-correlation matrix (Table 10). The correlations between $\mathrm{INT}_{2}$ and overall LPT index (ASX300PT), domestic-LPT index (DLPT $)$, domestic-commercial LPT index $\left(\mathrm{DCOM}_{2}\right)$, domestic-diversified LPT index $\left(\mathrm{DDIV}_{2}\right)$ increase slightly, while other correlations decrease marginally. The average correlation between the international-LPT index and the other domestic LPT sub-sector indices decreases slightly to 0.54 .

Table 12: Correlation matrix (Dec 1998 - June 2002)

\begin{tabular}{l|cccccccc}
\hline & $\mathrm{INT}_{2}$ & $\mathrm{DLPT}_{2}$ & $\mathrm{DRET}_{2}$ & $\mathrm{DCOM}_{2}$ & $\mathrm{DIND}_{2}$ & $\mathrm{DDIV}_{2}$ & $\mathrm{DHOT}_{2}$ & ASX300PT \\
\hline $\mathrm{INT}_{2}$ & $\mathbf{1 . 0 0 0}$ & & & & & & & \\
$\mathrm{DLPT}_{2}$ & $\mathbf{0 . 7 2 7}$ & 1.000 & & & & & & \\
$\mathrm{DRET}_{2}$ & $\mathbf{0 . 7 1 2}$ & 0.943 & 1.000 & & & & & \\
$\mathrm{DCOM}_{2}$ & $\mathbf{0 . 6 0 0}$ & 0.842 & 0.772 & 1.000 & & & & \\
$\mathrm{DIND}_{2}$ & $\mathbf{0 . 4 8 7}$ & 0.759 & 0.665 & 0.710 & 1.000 & & & \\
$\mathrm{DDIV}_{2}$ & $\mathbf{0 . 7 2 0}$ & 0.977 & 0.884 & 0.783 & 0.721 & 1.000 & & \\
DHOT $_{2}$ & $\mathbf{0 . 1 6 1}$ & 0.120 & -0.029 & -0.030 & 0.286 & 0.148 & 1.000 & \\
ASX300PT & $\mathbf{0 . 7 7 9}$ & 0.992 & 0.944 & 0.859 & 0.772 & 0.970 & 0.130 & 1.000 \\
\hline
\end{tabular}


Efficient portfolios were reconstructed applying these recalibrated indices over 1998 to 2002. Figure 9 illustrates the comparison of optimal portfolios for two different periods. As suggested by the lesser performance of $\mathrm{INT}_{2}$ during the Dec 1998 - June 2002 period, the diversification gain by adding international LPTs to domestic LPTs portfolio is not as significant as compared to the June 1997 - June 2002 period. However, the mixed international and domestic LPTs portfolio was still dominating the domestic LPTs portfolio in both periods.

As demonstrated in Figures 6 and 9, at all levels of risk/return spectrum, the addition of the international-LPT index has significantly added diversification benefits to the property trusts portfolio. The result is consistent with the findings of Gordon et al (1998), Maurer and Reiner (2002) and Liu and Mei (1998), where significant diversification benefits were found when international LPTs were added to the portfolio.

Figure 10 depicts the allocation of LPT sectors in the efficient portfolio across various risk levels over Dec 1998 to June 2002. The allocation to international LPTs is not as significant as in Figures 5 and 7 . However, the international-LPT index still warrants more than a $10 \%$ allocation at all risk levels below the $6 \%$ level of portfolio risk. The allocation to $\mathrm{INT}_{2}$ is reduced dramatically at higher portfolio risk levels. This clearly demonstrates the significance of $\mathrm{INT}_{2}$ in efficient portfolios and the contribution of international LPTs in property trust portfolios to diversification gains.

Figure 9: Comparison of efficient portfolio for 2 different periods: June 1997 June 2002 and Dec 1998 - June 2002

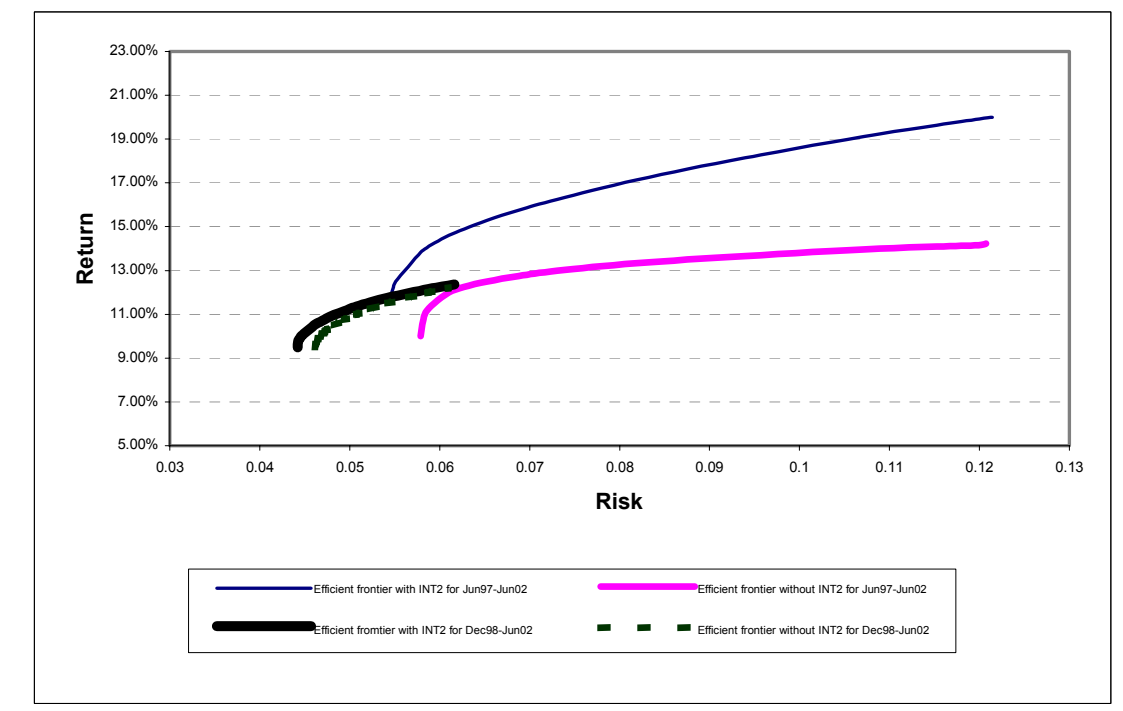

Pacific Rim Property Research Journal, Vol 10, No 1 
Figure 10: Efficient LPTs Portfolio: Dec 1998 - June 2002

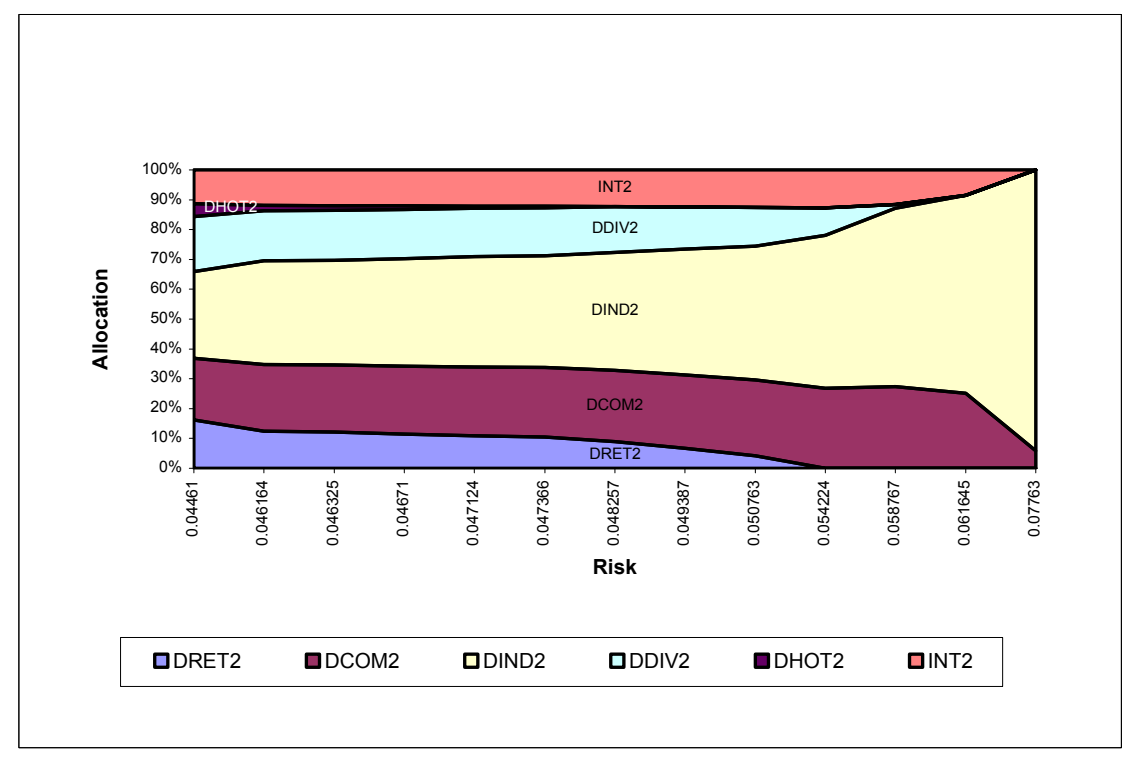

\section{PROPERTY INVESTMENT IMPLICATIONS}

To provide property securities investors and fund managers with more information about the returns on international properties in Australian LPTs, an index that tracks the performance of international LPTs can be very useful. Indeed, the internationalLPT indices ( $\mathrm{INT}_{1}$ and $\mathrm{INT}_{2}$ ), which track performance from June 1997 to June 2002 should be especially useful to small and medium property securities investors and fund managers since many may not invest directly in overseas property.

High costs of diversification and minimising unsystematic risk, high transaction and information costs, and problems of liquidity and management are factors cited as major deterrents for pension/property funds, especially smaller funds, to diversify their property portfolio internationally (McAllister, 1999). Moreover, as suggested by Lowrey (2002), an allocation of $20 \%$ to $30 \%$ in international property is needed to realise the diversification advantage of investing internationally. If the size of the international allocation is too small, the range of potential portfolio strategies would be limited.

However, the development of pooled international property investment vehicles (i.e. international LPTs discussed in this paper) have catered for the demand for international property exposure for Australian property securities investors and fund 
managers. Furthermore, international LPTs allow the separation of the international property investment decision into property-specific diversification (by geographic/economic region) and asset allocation decisions. Property-specific diversification decisions will be performed by property trust managers, while how much should be allocated to international property will be determined by the property securities investors and fund managers.

As discussed in Anderson and Shain (2001), Fisher and Liang (2000a,b) and Newell et al (2003), although not directly related to international LPTs, the authors found that it was more efficient and cost effective for property trusts to focus on one property sector to attain optimal geographic region diversification. Investors and analysts often prefer pure plays in property sectors (Fisher and Liang, 2000b). More importantly, it is easier for investors/fund managers to diversify their property securities investments than for property trusts to diversify their portfolios of property.

For property securities investors and fund managers, the development of a pure international LPT performance index (INT) will aid the asset allocation decisions and performance benchmarking. Furthermore, the findings of this paper also suggest that the addition of international LPTs in the Australian property trust portfolio has resulted in diversification gains.

There are several limitations surrounding this paper. The objective of this paper is to develop an international-LPT index which tracks the performance of international properties held in LPTs. Currency hedging and exchange rate fluctuations are two important aspects in international property investment. Capital structure is another major feature of performance. All these issues are not discussed in this paper but warrant future research. This paper assumes that the tasks of determining a hedging strategy and optimal capital structure rest on the property trust manager, instead of with property securities investors and fund managers. This is consistent with the notion of separation of property investment decisions.

The answer to the question of why not use property indices from overseas countries to develop international property benchmarks lies in the distinction between direct investment in overseas property and investment in international property held by LPTs. The appropriate benchmark for the former is a multi-country property index, while an international-LPT index is adequate for the latter.

A limitation of this paper is the methodology for Option 2, which assumes the contribution of international property in LPTs is proportionate to its weight in the portfolio, although the Option 2 methodology is exploratory in nature. When more LPTs hold both international and domestic properties, this assumption will increase correlation coefficients between the international-LPT index and other LPT sectors where the partial international LPTs are both incorporated. The rationale behind 
this concern is that returns from international property and domestic property in the same partial international LPT will be perfectly correlated $(+1.0)$. In addition, replicating the international-LPT index, particularly $\mathrm{INT}_{2}$, is impossible without committing to both international and domestic components of partial international LPTs at the same time.

Heavy reliance in a single LPT (i.e. WFA) also poses a potential bias to the international-LPT index. Although the numbers of international LPTs currently in this international-LPT index are small, this is expected to increase significantly in the next two years as more LPTs $^{6}$ in Australia seek international property investment opportunities. As such, this international-LPT index will take on enhanced stature for ongoing LPT performance analysis.

\section{REFERENCES}

Australian Stock Exchange. 2000. 2000 Australian share ownership study. ASX: Australia.

Australian Stock Exchange. 2002. Property trusts summary: Listed Property Trusts. ASX: Australia.

Addae-Dapaah, K. and Yong, C. 2000. Diversification of real estate investment in the Asia-Pacific region. Pacific Rim Property Research Journal, Vol. 6, No. 2, 3145 .

Anderson, R. and Shain, J. 2001. REIT returns by economic location: implications for asset allocations. Prudential Real Estate Investors Research, July.

Bailey, J. 1992a. Evaluating benchmark quality. Financial Analysts Journal, May-June, 33-39.

Bailey, J. 1992b. Are manager universes acceptable performance benchmarks? Journal of Portfolio Management, Spring, 9-19.

Bailey, J., Richards, T. and Tierney, D. 1988. Benchmark portfolios and the manager/plan sponsor relationship. Journal of Corporate Finance, Winter, 25-32.

\footnotetext{
${ }^{6}$ Recent listing of Macquarie ProLogis (specialising in North America distribution facilities property) on the ASX; AMP Diversified Property Trust has acquired 3 New Zealand retail properties in AugustSeptember 2002; Principal Financial Group plans to list a substantial portfolio of US office buildings (and also targeting Asia property) on the ASX; Macquarie plans to list a portfolio of US apartment properties.
} 
Barry, C., Rodriguez, M. and Lipscomb, J. 1996. Diversification potential from real estate companies in emerging capital markets. Journal of Real Estate Portfolio Management, Vol. 2, No. 2, 107-118.

Calder, S. 2002. Offshore investment opportunities. BT Real Estate Fund Management.

Cheng, P., Ziobrowski, A., Caines, R. and Ziobrowski, B. 1999. Uncertainty and foreign real estate investment. Journal of Real Estate Research, Vol. 18, No. 3, 463-479.

Chua, A. 1999. The role of international real estate in global mixed-asset investment portfolios. Journal of Real Estate Portfolio Management, Vol. 5, No. 2, 129-137.

Conover, M., Friday, S. and Sirmans, G. 2002. Diversification benefits from foreign real estate investments. Journal of Real Estate Portfolio Management, Vol. 8, No. 1, 17-26.

De Wit, D. 1997. Real estate diversification benefits. Journal of Real Estate Research, Vol. 14, No. 1/2, 117-135.

Divecha, A, and Grinold, R. 1989. Normal portfolios: issues for sponsors, managers and consultants. Financial Analysts Journal, March-April, 7-13.

Eichholtz, P. 1996. Does international diversification work better for real estate than for stocks and bonds? Financial Analysts Journal, Jan-Feb, 56-62.

Eichholtz, P. 1997a. Real estate securities and common stocks: a first international look. Real Estate Finance, Spring. 70-74.

Eichholtz, P. 1997b. How to invest internationally? Region and property type on a global scale. Real Estate Finance, Fall, 51-56.

Eichholtz, P., Gaaf, N., Kastrop, W. and Veld, H. 1998. Introducing the GPR 250 property share index. Real Estate Finance, Spring, 51-61.

Eichholtz, P., Huisman, R., Koedijk, K. and Schuin L. 1998. Continental factors in international real estate returns. Real Estate Economics, Vol. 26, No. 3, 493-509.

Eichholtz, P. and Koedijk, K. 1996. The global real estate securities market. Real Estate Finance, Spring, 76-82. 
Fisher, J. and Liang, Y. 2000a. Is sector diversification more important than regional diversification? Real Estate Finance, Fall, 35-40.

Fisher, J. and Liang, Y. 2000b. The relative importance of sector versus regional diversification. Prudential Real Estate Investors Research, June.

Garvey, R., Santry, G. and Stevenson, S. 2001. The linkages between real estate securities in the Asia-Pacific. Pacific Rim Property Research Journal, Vol. 7, No. $4,240-258$.

Gordon, J., Canter, T. and Webb, J. 1998. The effect of international real estate securities on portfolio diversification. Journal of Real Estate Portfolio Management, Vol. 4, No. 2, 83-91.

Kaplan, P. and Alldredge, R. 1997. Semi variance in risk-based index construction: Quantidex Global Indexes. Journal of Investing, Summer, 82-87.

Liu, C. and Mei, J. 1998. The predictability of international real estate market, exchange rate risks and diversification consequences. Real Estate Economics, Vol. 26, No. 1, 3-39.

Lowrey, C. F. 2002. A framework for constructing international real estate portfolios. Prudential Real Estate Investors, Prudential Financial, Feb. 2002.

McAllister, P. 1999. Globalisation, integration and commercial property, evidence from the UK. Journal of Property Investment and Finance, Vol. 17, No. 1, 8-26.

McIntosh, W. 1997. Real estate portfolio benchmarking. Journal of Real Estate Portfolio Management, Vol. 3, No. 1, 75-77.

Maurer, R. and Reiner, F. 2002. International asset allocation with real estate securities in a shortfall risk framework: the viewpoint of German and U.S. investors. Journal of Real Estate Portfolio Management, Vol. 8, No. 1, 27-43.

Maxwell, K. and Saint-Pierre, P. 1998. Benchmarking real estate investment performance: the application of real estate indices. Journal of Property Management, May/June, 64-68.

Newell, G., Lee, S. and Stevenson, S. 2003. The role of market timing and property selection in Listed Property Trust performance. Proceedings of Pacific Rim Real Estate Society Conference, Brisbane.

Newell, G. and Webb, J. 1996. Assessing risk for international real estate investments. Journal of Real Estate Research, Vol. 11, No. 2, 103-115. 
Newell, G. and Worzala, E. 1995. The role of international property in investment portfolios. Journal of Property Finance, Vol. 6, No. 1, 55-63.

Oliphant, M. and Corgel, J. 1989. Real estate index measures performance of open, closed funds. Pension World, January, 18-22.

Property Investment Research. 2002. Monthly report, December 2002 (and miscellaneous 1998-2002 copies), PIR: Melbourne.

Property Investment Research. 2003. Annual Listed Property Trust Review - 2003 (and miscellaneous 1998-2002 copies), PIR: Melbourne.

Steinert, M. and Crowe, S. 2001. Global real estate investment: characteristics, portfolio allocation and future trends. Pacific Rim Property Research Journal, Vol. 7, No. 4, 223-239.

Stevenson, S. 1999. Real estate's role in an international multi-asset portfolio: empirical evidence using Irish data. Journal of Property Research, Vol. 16, No. 3, 219-242.

Stevenson, S. 2001. The long-term advantages to incorporating indirect securities in direct real estate portfolios. Journal of Real Estate Portfolio Management, Vol. 7, No. 1, 5-16.

Webb, J., Curcio, R., and Rubens, J. 1988. Diversification gains from including real estate in mixed-asset portfolios. Decision Sciences, Vol. 19, 434-452.

Wilson, P. and Okunev, J. 1996. Evidence of segmentation in domestic and international property market. Journal of Property Finance, Vol. 7, No. 4, 78-97.

Wilson, P. and Okunev, J. 1999. Long-term dependencies and long run nonperiodic co-cycles: real estate and stock markets. Journal of Real Estate Research, Vol. 18, No. 2, 257-278.

Worzala, E. and Newell, G. 1997. International real estate: a review of strategic investment issues. Journal of Real Estate Portfolio Management, Vol. 3, No. 2, 8796.

UBS Warburg 2002. UBS Warburg Indices: September 2002 (miscellaneous copies and data in spreadsheet). UBS Warburg: Sydney. 